\title{
Biology and the Nation in Germany
}

$\mathrm{T}$ $\mathrm{HE}$ administrative appreciation of the biological outlook in national development is nowhere so evident to-day as in Germany and Soviet Russia. A brief account of the current exhibition in Berlin on "Das Wunder des Lebens", which crystallises the use and abuse of biology by the third Reich, may therefore have some general interest. The policy on which it is based was outlined by Dr. Frick, Reichsminister of the Interior, in his inaugural speech on March 23. Unlike the 'liberalistisch-marxistichen' regime, he said, National Socialism views the individual as an inseparable part of the family, and the family as the basis of the nation. The individual therefore has increased duties to the State, but receives in return more rights, more protection, and the immediate promise of a happier and healthier life. secured through education, eugenic legislation and social assistance by the State. It is significant that he did not take a narrow national view of these activities. Indeed, he hoped that the Exhibition would be regarded as a renewed token of international friendship, and expressed the belief that the German people are anxious to work in a spirit of amiable co-operation not only for themselves but also for the growth of a healthy Europe.

Conceived in this spirit, the Exhibition is presented with a freshness and technical excellence which one expects from the organisation behind it -the Deutsches Hygiene-Museum at Dresden. It is also noteworthy that it makes no demand on the State budget, advertisers providing the cost and visitors an anticipated profit. Two halls concerned with 'Bekleidung-Schmuck' and 'Ernährung' are entirely devoted to products which not only harmonise with the motif of the Exhibition, but also supplement the technical halls in a most attractive manner. The first and most interesting of these scientific halls deals with 'Die Lehre vom Lebens', and is approached through an impressive 'Ehrenhalle' dominated by a monumental relief (Empor) symbolising the release of the German people under the new administration. Among the exhibits, the place of honour is given to 'The Transparent Man', a model under automatic electrical control which illuminates and explains each system of the body in turn. It is a masterpiece of museum technique, enshrined in a darkened chamber in which these words of Augustinus are prominently inscribed :

"Es bewundern die Menschen das rauschende Meer,

Die fliessenden Gewässer und den Anblick des Himmels,

Und vergessen über allem Bewundern der Dinge Das Wunder, das sie selber sind."

In the main body of this hall, working models and striking diagrams demonstrate the elements of anatomy and physiology in relation to personal and public health. A lattice tower, for example, shows that the daily energy involved in the mechanism of the heart could take two persons to the top of the 'Funkturm' (138 metres high) adjoining the Exhibition. Nearby a large wire cage illustrates the average volume of air (32 cubic metres) required by a man in one day, while neighbouring exhibits indicate respiratory needs during various activities and postures, and the relation between the respiratory and circulatory systems. A square relief conspicuous on the ceiling represents the surface area of the normal number of red blood corpuscles in man. Among the working models, of particular interest are those concerned with the circulation of the blood, the importance of water, the processes of digestion and the time taken to digest various foods, the mechanism and causes of dreams, the cerebral area involved in different actions, the location of bodily pains and the possible diseases they indicate, the functions of the ductless glands and their correlation with abnormalities, and the discrimination of 'basic smells', which visitors may experience for themselves. A small cinema shows biological films ranging from cellular activities to the intelligence of monkeys, while a section for 'Biologische-Leistungsprüfungen' oncourages visitors to test their own lung capacity, vocal range, cardiac normality and colour vision.

From this hall one passes over an attractive 'Terrasse Restauration', with a symbolic fountain, to that which deals with 'Der Träger des Lebens'. An ante-chamber, decorated with impressive reliefs and diagrams of vital statisties in Europe, emphasises the importance attached to a large population of working-class families in the new Germany. In the centre, a 'Glockenturm' rings out the information that nine children are born in Germany every five minutes, while at the base of the structure a huge hour-glass records the death of seven persons during the same period. Two quotations from the Chancellor's "Mein Kampf" illustrate the spirit in which this hall is conceived. One is the familiar "Honour the work and honour the worker", while the other sermonises more voluminously as follows: "Auch die Ehe kann nicht Selbstwert sein, sondern muss dem einen grösseren Ziele, der Vermehrung und Erhaltung der Art und Rasse, dienen". To the right of this chamber is a nursery where the children of visitors can rest and play.

Passing into the main hall, one is confronted with an imposing illuminated exhibit, dominated by the national emblem, showing that National Socialism endeavours to protect every aspect of family life from childhood to old age. Freely translated, the words written over the eagle state that "The hereditary healthy family is the basis of life. The maintenance of their ability to work, and their protection and education in self-help, is therefore one of the great tasks of the NSDAP". And the most confirmed opponent of dictatorship must admit that the new party has attacked that task with commendable energy. One sees in this hall the results of a determined effort for the betterment of the family, through such avenues as education and care of mothers and children, the training of the average girl for her share in the development of the State, and poor-relief measures extending from the provision of food, clothes and coal to travelling schools and clinics which tour the districts. The central organisation. for these activities, which cover the entire country, is the NS.Volkswohlfahrt, the funds of which are largely obtained from voluntary subscriptions, street collections from the sale of badges made by the rural workers, and so on. In the winter a special effort is made, its success being partly indicated by the fact that nearly 360 million marks were contributed to 'Winterhilfswerk' in the winter of 1933-34. The 
monthly 'Eintopfgericht' Sunday alone, when a majority of the population contributes to 'winterhelp' the savings resulting from restricting the midday meal to one dish, provided more than 25 million marks.

The next hall, 'Die Erhaltung des Lebens', illustrates the protection of public health in all its aspects, and the visitor can see in it many of the latest devices of preventive and curative medicine, ranging from occupational therapy and radium treatment to the latest Junkers 'Sanitätsflugzeuges'. The sanitary and educational activities of the Nazi party are also amply illustrated. A feature of the hall is a model marriage consultation centre, to which attention is attracted by illuminated curves, correlated with pictures of social conditions, of the birth-and deathrates since 1820. They show that the birth-rate rose from 1820 until 1875 , and fell in response to increasing industrialisation between 1875 and 1933, when it again assumed an upward trend. The inclination of the death-rate follows, as usual, that of the birth-rate. The elevation of the birth-rate in the new regime has been secured not only by propaganda but also by State aid, 20 marks a month being given for each child in families of more than three children, provided they are 'racially healthy'. It should be added that these consultation centres will increase in importance, for further measures for the betterment of national health are to be introduced very shortly, including legislation for health certificates before marriage.

Special attention is also paid to racial 'purity', Gobineau being given an important niche in the portrait gallery of great men who have influenced the Nazi philosophy. In one popular section the Nordic farmer and fighter is glorified in pictures reminiscent of juvenile editions of the "Nibelungensage", surmounted by the statement that "There is nothing more precious on this earth than the seeds of noble blood". On the opposite wall a quotation from "Mein Kampf"' stands out in equally bold relief : "Indem ich für die Deutsches Zukunst kämpfe, muss ich kämpfen fur die Deutsche Scholle, und muss ich kämpfen fur den Deutschen Bauern". In an adjoining section a propagandic pedigree of the 'Führer' emphasises his association with the peasant class. The inevitable Jew-baiting takes the form of a series of 'selected' pictures of Semitic types bearing the sarcastic legend "Der Jude Harry Chaim genannt Heinrich Heine sagt im Buch der Lieder : 'Alle Menschen gleich geboren, sind ein adliges Geschlecht'." Alongside are several anti-Semitic cartoons, supported by Herr Hitler's opinion that the Jew can never be a German and that he will always work for the 'Grossere Idee' of his own race. The organisers of the Exhibition would have done better if they had refrained from degrading an otherwise excellent scientific exhibition with such propaganda.

The Exhibition concludes with a 'Mikrovivarium' and a section entitled 'Wohnung and Siedlung'. In the former, living micro-organisms and parasites are projected on a screen and explained by attendant demonstrators. In the latter, a series of models illustrates the improvement of housing conditions for the working classes, the central attraction being a full-size example of the suburban houses provided for working men. As one leaves the Exhibition, one feels that modern Germany has not only caught something of the spirit of the lines which adorn the cover of this journal, but has also succeeded to an admirable degree in translating it into practice.

I am indebted to the Hon. Mrs. Ursula Grant Duff and Dr. Bruno Gebhard, scientific director of the Exhibition, for many courtesies in connexion with my biological inquiries in Germany.

Cenric Dover.

\section{Constitution and Properties of Some Non-Ferrous Metals and Alloys}

$\mathrm{T}$ $\mathrm{HE}$ spring meeting of the Institute of Metals was held on March 6-7, in the hall of the Institution of Mechanical Engineers.

To all interested in the lead-tin-antimony alloys, and particularly those used for type metals, the paper by Frances D. Weaver will be of especial value. In addition to the working out of at any rate the main features of this diagram, a considerable amount of data is available concerning the hardness properties of those alloys most commonly employed.

Prof. D. Hanson, in collaboration with Mr. E. J. Sandford, has continued his work on the influence of small amounts of other elements on the properties of tin. The metals investigated in the present work are aluminium, manganese and bismuth, the results with the first metal being perhaps particularly important in that there is a very definite time effect. The greatly improved properties obtained immediately after preparation are not permanent; deterioration of the alloy commences at the skin and spreads slowly inwards and spontaneous cracking takes place. Bismuth also increases the tensile strength of tin very considerably and refines the grain size.

Mr. W. E. Prytherck has examined the mechanical properties of some wrought magnesium alloys, and although no alloys of this metal have yet been produced which respond to heat treatment in the manner which is characteristic of certain well-known aluminium alloys, some of the materials studied have distinctly interesting and promising properties. The work which they have carried out over a number of years on the investigation of unsoundness in aluminium alloy castings is continued by Prof. Hanson and Mr. I. G. Slater, who have examined the effect of the pressure of the atmosphere under which a metal solidifies. They have shown that pressures from fifty to a hundred pounds per square inch are sufficient to remove all visible traces of pin-holes from sand-cast ingots, and that the densities of such castings, particularly those prepared under the higher pressures, are appreciably greater than can be obtained from ingots poured from melts treated by the various de-gassing processes. The tensile properties of certain alloys are considerably improved by solidification under pressure, but the fact is noted that in some instances, reheating the casting, by causing the liberation of the gases contained in solution, may give rise to blisters and cavities.

The penetration of molten solders into strained non-ferrous metals has been examined by a number of workers. Mr. L. J. G. van Ewijk contributes an account of a similar type of cracking in heat-treated nickel-chromium steel. The zine chloride flux is shown to be innocuous, and it is clear from the intercrystalline nature of the fracture that the penetration here is of exactly the same order as that which has been found in non-ferrous alloys. One of the interesting 